\title{
CONSTRUCCIÓN DEL TERROR EN CUENTOS MALÉVOLOS DEL ESCRITOR PERUANO CLEMENTE PALMA
}

\author{
Jesús Miguel Delgado del Águila \\ Universidad Nacional Mayor de San Marcos \\ tarmangani2088@outlook.com
}

Recibido: 23-01-2020

Aceptado: 29-04-2021

\section{RESUMEN}

Para este artículo, asumo las ediciones publicadas de Cuentos malévolos, compendio de relatos con un abordaje crítico de los valores y las ideologías tradicionales del Perú a inicios del siglo xx, con el fin de construir un panorama de su exégesis literaria y analizar la inclusión autoral de una variante novedosa del terror, distinguida por el desarrollo de elementos decadentes del romanticismo. Para la comprensión de esta cosmovisión inusitada regida por la maldad, será indispensable adoptar el tratamiento del amor y su percepción autónoma como ejes de sus narraciones.

Palabras ClaVe: terror; lo fantástico; psicodinamismo; estudios críticos; romanticismo.

\section{THE CONSTRUCTION OF TERROR IN MALEVOLENT TALES BY THE PERUVIAN WRITER CLEMENTE PALMA}

\section{ABSTRACT}

This article presents an overview of the literary exegesis made of the published editions of Malevolent Tales, a compendium of stories with a critical approach to the values and traditional ideologies of Peru at the beginning of the 20th century. It analyzes as well the authorial inclusion of a variant novel of terror, distinguished by the development of decadent elements of romanticism. The adoption of love and its autonomous perception as axes of these tales will be essential for understanding their unusual worldview dominated by evil.

KeYWORDS: terror; the fantastic; psychodynamics; critical studies; romanticism. 


\section{INTRODUCCIÓN}

Primero, se considerarán las múltiples ediciones que se han publicado de Cuentos malévolos, puesto que se encuentran variaciones estilísticas, lingüísticas y ortográficas que se adaptan a la normativa de la Real Academia Española, conforme transcurre el tiempo. Asimismo, se van incorporando nuevos relatos que constituyen la totalidad del compendio de la obra narrativa de Clemente Palma. Las versiones con las que se cuentan son la de Barcelona (1904), la de París (1912), la de Nuevos Rumbos (1959), la de Peisa (1974) y la de la Pontificia Universidad Católica del Perú (2006).

Segundo, efectuaré un estudio en torno a lo que ha investigado la exégesis literaria sobre sus cuentos. Para realizarlo, confrontaré con las tradiciones que influyeron en el autor, tales como el modernismo, el decadentismo, lo fantástico, lo gótico, el romanticismo y la ciencia ficción. Además, es de interés forjar la cosmovisión de Clemente Palma para comprender la ideología transferida en sus relatos. Por ejemplo, los factores que están presentes son sus percepciones sobre el satanismo, el racismo, la locura y el ateísmo. Es más, importa cómo se ha consolidado su narrativa; en rigor, los recursos literarios que se han utilizado para que se cumpla su propósito, como también los elementos insoslayables que permitieron la aproximación con personajes que se caracterizan por la maldad (como el Diablo) y la rebeldía ante la imposición de la época del sistema religioso secular (esto origina que adrede se tergiversen las doctrinas bíblicas).

Tercero, exhibo como categoría una variante, denominada terror romántico, que consiste en la difusión de ese estado repulsivo supeditado a criterios propios de la poética de Edgar Allan Poe, como los que se exponen en Narraciones extraordinarias. A la vez, debe tenerse en cuenta que los temas que se desarrollan en los textos de Palma recurren consuetudinariamente a las vicisitudes de las relaciones de pareja y el amor en su ipseidad. A partir de esta determinación, se postulará el terror para acarrear situaciones anómalas, desequilibradas y opuestas al catolicismo.

Finalmente, con un análisis personal, me baso en el concepto de terror para inferir constantes que se exteriorizan en los relatos del autor, como la predominancia de que el mal siempre triunfe sobre el bien, la construcción eficaz de escenarios sórdidos y oscuros, los personajes que padecen de una alteración mental asociada con su forma de percibir la realidad o el romance, la función de la maldad en el texto, las reiteradas reformulaciones de apreciar lo espiritual desde la perversidad, el rechazo del catolicismo y la introducción del suspenso. 


\section{Ediciones de Cuentos malévolos (1904)}

Retomaré las ediciones que se han hecho de Cuentos malévolos, con la finalidad de hallar cambios o aditamentos al mismo. En total, fueron cinco. Estas se publicaron en los años 1904, 1912, 1959, 1974 y 2006 respectivamente. A continuación, se explicarán las variaciones, según cada aparición.

La primera edición procede de Barcelona (1904). Consta de doce cuentos: «Los canastos», «Idealismos», «El último fauno», «Parábola», «Una historia vulgar», «Los ojos de Lina», «Cuento de marionetas», «El quinto evangelio», «La última rubia», «El hijo pródigo», «La granja blanca» y «Leyenda de Hachisch». Tiene consigo el prólogo realizado por Miguel de Unamuno. Esta es localizable en la biblioteca de la Facultad de Letras y Ciencias Humanas de la Universidad Nacional Mayor de San Marcos (UNMSM, Lima, Perú), puesto que ya está agotada. Por esa razón, no ha sido accesible en esta oportunidad. No obstante, en el buscador virtual de Google Docs, tan solo es visible el índice de sus narraciones. Por otro lado, la versión de Peisa menciona que esta conserva la ortografía de la primera edición.

La segunda edición, publicada en París (1912), es modificada por la inclusión de ocho relatos, a diferencia de la primera edición. En ese sentido, Cuentos malévolos se conforma por veinte narraciones, recopiladas en la edición de la Pontificia Universidad Católica del Perú (2006). Por otro lado, en esa versión, ya no aparece el prólogo de Miguel de Unamuno, sino el de Augusto Tamayo Vargas. De la misma manera, esta se encuentra agotada, aunque se conserva en la Biblioteca Central de la Universidad Nacional Mayor de San Marcos.

La tercera edición, de Nuevos Rumbos (1959), contiene solo los doce relatos iniciales de la primera edición. Lleva consigo el prólogo de Miguel de Unamuno, con criterios que ya no son notorios en ediciones postremas. Verbigracia, en esta, se cuenta con palabras en negrita (incluso se emplean las mayúsculas) en vez de recurrir a las cursivas: «Cuentos Malévolos» (1959: 7), «de tal palo tal astilla» (1959: 7), «Cuento de Marionetes» (1959: 8), «Plenitud de plenitudes y todo plenitud» (1959: 8), «CUENTOS MALEVOLOS» (1959: 8), «El último fauno» (1959: 8), «El quinto Evangelio» (1959: 9), «El hijo pródigo» (1959: 9), «Miguel de Unamuno. Salamanca, 17 de Abril de 1904» (1959). Este uso de negritas constantes se corrobora a lo largo de todos los relatos, al igual que la tildación innecesaria de las sílabas «a» y «o» (en el prólogo y los cuentos); por ejemplo, en «Los canastos»: «Ya viene el tiempo en que no vives sino gruñendo y blasfemando, en que nos aporreas á tus hijos y á mí» (1959: 13), en 
«El quinto evangelio»: «Sólo que lo hacían en unos idiomas extraños» (1959: 64), junto con la tildación de monosílabos en este último cuento: «Poco á poco fué saliendo la luna é iluminó con sarcástica magnificencia» (1959: 61). En relación con el contenido, es similar. Solo se modifica el estilo.

La cuarta edición, que le pertenece a Peisa (1974), es cambiada porque se le incorpora la «Presentación» de Augusto Tamayo Vargas, previa al prólogo de Miguel de Unamuno. Luego de este, se muestra un anuncio del editor (en negrita), en el que se menciona que los cuentos están basados en el texto original de 1904; incluso, se ha considerado su ortografía:

La presente edición de CUENTOS MALÉVOLOS es copia de la edición primera, impresa por Salvat en Barcelona en 1904. Lleva, como aquélla, prólogo de don Miguel de Unamuno; el cual fuera suprimido en ediciones posteriores. Se ha respetado, por otra parte, la ortografía del original (Palma, 1974).

En esta, se expresan frases en negrita, tildación de palabras como «sólo», «á», «ó», «fué» y un uso superfluo de mayúsculas. La edición contiene los doce relatos iniciales de la primera edición y se añade como decimotercero el cuento «El príncipe alacrán».

La quinta edición, que está a cargo de la Pontificia Universidad Católica del Perú (2006), patentiza el lenguaje de Clemente Palma actualizado. Si se toman las reglas ortográficas vigentes de la Real Academia Española (2020), se hallan variaciones a nivel de la normativa castellana. En esta, las palabras que aparecen en negrita están con cursiva en su mayoría. Para hacer referencia a los relatos, se les añade comillas; verbigracia, «El último fauno» y el mes de «abril» se encuentran en minúscula. Consta de veinte narraciones. Estas son las siguientes: «Los canastos», «Idealismos», «El último fauno», «Parábola», «Una historia vulgar», «Los ojos de Lina», «Cuento de marionetas», «El quinto evangelio», «La última rubia», «El hijo pródigo», «La granja blanca», «Leyenda de Hachisch», «Tengo una gata blanca», «Ensueños mitológicos», «El príncipe alacrán», «Un paseo extraño», «El nigromante», «Las vampiras», «El día trágico» $\mathrm{y}$ «Las mariposas». Posee los prólogos de Miguel de Unamuno (se aprecia en la primera edición) y Ventura García Calderón (en la segunda edición), titulado «El viaje singular del señor Palma». Además, retoma la obra completa del autor, y también exhibe relatos inéditos, como "Andrónico», «Mensaje de amor», «Walpurgis», «El carnaval de las flores», «Dmitri», «La derrota de Venus», «El credo de un borracho», «Anacreonte ebrio», «El mejor regalo», «Las queridas de humo», «Los faunos viejos» y «Elogio y diatriba», que conforman Otros cuentos malévolos (no recapitulados en el libro). 
Por lo tanto, la última edición de este texto incorpora todos los cambios gramaticales y de contenidos. Esto conlleva una lectura amplia, vigente y provechosa de los relatos de Clemente Palma.

\section{Estudios CRíticos SObre Cuentos maLÉVOlos (1904)}

En esta oportunidad, desplegaré las propuestas efectuadas en torno a este libro, junto con una crítica personal. Estos estudios remiten a cuatro criterios que servirán para delimitar el tema de investigación del artículo. El primero aborda el tópico de las adscripciones de las tradiciones por parte del autor para la elaboración de su texto, como el modernismo, el decadentismo, lo fantástico, lo gótico, el romanticismo y la ciencia ficción. El segundo consiste en la ideología que manifiesta el autor y su participación en lo social. El tercero abarca la exégesis realizada de Cuentos malévolos. Para finiquitar, se expondrán los trabajos proferidos acerca de la introducción de lo terrorífico.

\subsection{Influencia de tradiciones}

Para este segmento, se evidencia la intervención de la crítica literaria. Esta ha intentado clasificar y detectar las estribaciones directas que han repercutido en la obra de Clemente Palma, como al catalogarlo como exponente del modernismo con el decadentismo, lo fantástico, lo gótico, el romanticismo y la ciencia ficción.

Primero, el modernismo y el decadentismo están presentes. Al respecto, Rita Gnutzmann (1981) menciona que existen filiaciones explícitas de los narradores rusos (homenajeados en el cuento «Los canastos»), franceses (Maupassant y Nerval) y, sobre todo, de Poe. El esoterismo y los estados parapsicológicos permiten considerarlo en la línea de escritores modernistas latinoamericanos como Lugones, Quiroga y Nervo. Nancy Kason (1988) clasifica y analiza los treinta y dos relatos de Clemente Palma entre modernistas, heréticos, decadentes y fantásticos, luego repite el procedimiento con sus dos novelas. Se cerciora del autor adepto del modernismo, ya que no prevalece ni una intención por representar lo nacional. Se asocia con lo científico y se claudica de la fe religiosa. Pedro Pablo Viñuales Guillén (1991) plantea que el escritor peruano desarrolla una estética modernista, en especial, una decadente, que se comprueba desde su documentación. Independientemente, estudia 
múltiples cuentos para hallar temas vinculados con la estética decadente, como el futurismo en «Nigromante» y «La última rubia» o el doble en «La granja blanca». Para Gabriela Mora (2000), se trata de un modernista epónimo, que se caracteriza por sus ambivalencias y su ambigüedad. No obstante, esas particularidades son más notorias en el contexto posmoderno, en el que se aprecian rasgos relativos, ruptura de metarrelatos y fragmentarismo. De ello, se infiere que inicia su análisis erróneamente, a causa de que considera al autor como no canónico y no valorado por la exégesis en su debido momento: a inicios del siglo xx. Lo califica como decadente por inspirarse en autores y personajes satánicos, además de recurrir al tópico de las drogas, corroborado en Cuentos malévolos (Mora, 2000: 81). Esa atribución resulta menospreciable desde la percepción trabajada sobre el terror.

En relación con la taxonomía que recibe el libro con las tradiciones literarias, es asociada con el rechazo al realismo y el romanticismo, como una filiación con lo decadente, tal como lo indica en el siguiente fragmento: «La representación positiva de Lucifer —encarnación del Mal— hecha por románticos y decadentes, fue una de las armas de los modernos para atacar los valores burgueses más convencionales» (Mora, 2000: 63). Asimismo, Gabriela Mora (2006) se refiere a los relatos de Palma como modernistas (con evasión de códigos realistas y naturalistas, para plasmar espacios lejanos de la realidad y privilegiar el decadentismo). Ricardo Sumalavia (2006) posiciona al autor como un exponente del modernismo hispanoamericano, porque se observa el desarrollo de pensamientos filosóficos e incorporación de elementos malignos. Moisés Samuel Ysmael Sánchez Franco (2007) retoma la noción de modernismo para dilucidar la obra del cuentista peruano. María Julia Olijnyk (2013) analiza «El día trágico» e «Idealismos» y parte de la concepción de que el autor es modernista y decadentista, y de que su producción se basa en esa postura; en consecuencia, se manifiestan temáticas vinculadas con la muerte y el amor distorsionado. Para Wilmer Basilio Ventura (2014), Palma se distancia de lo nacional. Esto provoca su acercamiento al modernismo y el exotismo, incluso fantástico. Ricardo Sumalavia (2014) sostiene que esta obra fue patrocinada por el modernismo latinoamericano y el decadentismo europeo. Mateo Díaz Choza (2015) distingue y explica las clasificaciones heterogéneas que ha tenido Clemente Palma, como el modernismo, el decadentismo, el ateísmo y el anticlericalismo. Para finalizar, José Güich Rodríguez (2016: 48) aprecia el modernismo con una forma desgastada, ya que este se usó originalmente en Europa, y fue tardío en el Perú. Asimismo, la composición arbitraria a la que alude el autor en torno a la humanidad es notoria en su tesis doctoral, puesto que rectifica que las deno- 
minaciones establecidas se han modificado al través del tiempo. A ello, la política resulta un factor indispensable para incentivar esa transformación, tal como se exhibe en la siguiente cita: «El hombre moderno no es nada definido y completo: todas las creencias y todos los mitos cubiertos por el caparazón de la duda, han hecho madriguera en su corazón y en su cerebro. (...) Creyente ¿y por qué analiza?» (Palma, 1897b: 4).

Segundo, lo fantástico oscila en el libro. Al respecto, se encuentra el trabajo efectuado por Peter Elmore (1984), quien menciona que el autor funda la narrativa breve y fantástica en el país. Del mismo modo, Güich Rodríguez (2016: 55) comprueba la permanencia de elementos fantásticos en la narrativa de Clemente Palma, como el de recurrir a la ambigüedad, que se evidencia entre el mundo real y el ficcional. Para su demostración, corrobora la propuesta de Harry Belevan, publicada en Antología del cuento fantástico peruano (Güich Rodríguez, 2010), en la que sostiene que el cuentista es el fundador de la narrativa fantástica peruana, además de brindarse un panorama de sus exponentes. Esa disyuntiva perenne en su escritura también se aprecia en el planteamiento de su tesis doctoral (1897b), en la que explica que un sujeto andrógino sería la solución para que se eviten los contrastes entre los géneros. Esa percepción es arraigada luego de que formulara con sustentos empíricos e históricos cómo se rigió la humanidad supeditada a la religión y al rechazar el positivismo.

Tercero, lo gótico se expone en el texto. Sobre ello, se localiza el aporte de Encarnación López Gonzálvez (2014), quien se refiere a Palma como un autor afín, por la presencia de elementos necrofílicos, incesto y ocultismo. Lo gótico se caracteriza por ser transgresor: nadie quiere contarlo, provoca temor y se desbrida por entornos oscuros. Esto se comprende como una tradición gótica de corte anglosajón, que se articula en «La granja blanca», al igual que en las influencias de «El retrato oval», «Ligeia»y «Morella», de Edgar Allan Poe, debido a la configuración de los espacios, las situaciones y la mujer. Por ende, el cuentista peruano logra esas adhesiones intertextuales. Para Clemente Palma, este rasgo lóbrego es inminente para causar un efecto de terror, tal como lo argumenta en un determinado contexto social: "Como los niños tienen horror a la oscuridad, al vacío, necesita poblar las noches de visiones, las horas de descanso con ensoñaciones consoladoras, las treguas de los placeres materiales con locas lucubraciones religiosas, que jueguen con sus sentidos» (1897b: 8).

Cuarto, el romanticismo también está adscrito en su narrativa. En función de ello, Ricardo Sumalavia (2006) identifica la vinculación con Poe; en rigor, en «La caída de la casa Usher», en el que los temas del doble y el incesto se plasman. 
De la misma manera, esta filiación se exhibe por la actitud emancipadora de los personajes, que tienden a retroalimentarse del pasado. En cambio, Elton Honores (2013) señala que con el autor se aprecia una crisis entre ruptura y tradición, ya que se destacan talantes románticos, sin necesidad de que se abarque este tópico en su totalidad. Para Güich Rodríguez (2016: 49-53), son notorias las influencias del romanticismo que propagan Poe, Baudelaire, Rimbaud o Mallarmé, en cuanto a sus esencias estética y filosófica, de las cuales pretende distanciarse. En especial, algunos talantes de la poesía francesa se observarían a través de la representación de sus personajes en un estado entre la vigilia y el sueño. El cuentista recurre a este movimiento artístico al percatarse de indicios heteróclitos entre masculinidad y feminidad: «Son dos contrastes, dos puntales mal puestos para sostener el edificio de la raza, que necesitan ayudarse, complementarse para formar la entidad en su aspecto integral» (Palma, 1897b: 25).

Para terminar, se exterioriza la filiación con la ciencia ficción en Cuentos malévolos. Esta argumentación la desarrolla Kason (1988), quien se cerciora de esa peculiaridad en el discurso de Palma. Gabriela Mora (2000) especifica que esta orientación es evidente en el autor y pone como ejemplos «La última rubia» y «El día trágico». Posteriormente, Ricardo Sumalavia (2014) añade «La última rubia», que es el más instintivo en ese aspecto. Como ya se explicó, el escritor peruano tiene una inquietud por desentrañar el tipo de humanidad que sería equivalente a un cambio significativo para el transcurso del tiempo y su trascendencia cualitativa. En una primera instancia, propuso que la raza indígena no es la elegida para la posesión y la administración del futuro, por sus carencias y sus limitaciones intelectuales. En otra oportunidad, sustentó que el andrógino era la nueva entidad que alteraría el orden de la naturaleza, pero con un objetivo satisfactorio, ya que evitaría las diferencias sociales y culturales del hombre y la mujer.

\subsection{Ideología del autor o su participación en lo social}

En esta ocasión, fundamentaré los postulados de los exégetas que han detectado la presencia de patrones ideológicos perennes en la obra de Clemente Palma. Kason (1988) indica que sus cuentos están estribados en su tesis doctoral Filosofía y arte. Igual ocurre con Carlos Eduardo Zavaleta (1997), quien menciona al autor sujeto a su biografía, como su contacto con Miguel de Unamuno o la trascendencia literaria que le dejó su padre, Ricardo Palma. En este texto, el escritor peruano pormenoriza histórica y filosóficamente los 
cambios que han surgido en la humanidad y que son constatados a inicios del siglo $\mathrm{xx}$, como resulta al cotejar los estímulos laborales y sociales femeninos. Estos se concretan en una colisión interna con el sexo opuesto, quien ha asimilado más su conducta abnegada y poco alentadora. En ese sentido, su trabajo es un manifiesto a favor de propiciar las transformaciones sociales desde lo ideológico. Otro elemento más es el ateísmo, el cual se ha proyectado con una orientación macabra por cuestionar las doctrinas de la religión. Esa postura se condiciona a la confrontación consuetudinaria que se articula en las relaciones humanas, de las que no se llegan a representar sus ideales y sus acciones con absoluta conformidad y emulación, sino que imperan las refutaciones, las incógnitas y las transmutaciones. Otros tópicos como el satanismo y el androginismo repercuten en cuanto que el autor los formula desde una percepción que contribuiría a la aceptación de las diferencias ideológicas que prevalecen con sus contrapartes. El escritor evita que se construyan prejuicios ante lo desconocido, como el de justificar el satanismo por la ausente intervención de Dios para subsanar a los más necesitados o solucionar problemas globales. Lo mismo sucede con el androginismo, que es equivalente al hecho de reemplazar la noción que posibilita la conexión ontológica entre hombre y mujer.

Gabriela Mora (2000) identifica la burla hacia el racismo, como se observa en «La última rubia». En relación con el entorno de la época que se caracteriza por la ruptura de la moral, la investigadora vincula los temas de la muerte y el desarraigo de Dios en el autor, junto a la influencia ideológica de la filosofía de Nietzsche, tal como lo hace en su tesis de bachiller, titulada El porvenir de las razas en el Perú (1897a). En esta, señala que el contexto histórico ayudó a erigir al escritor, con la creencia de que la raza que se aproxime más a la española será la superior. Por ende, considera lo indígena como algo superfluo y banal, puesto que lo tomará como incapaz de administrar trabajos mayores y ambiciosos, por lo que su función se restringe a cumplir las delegaciones de sus jefes. Para Palma (1987a: 4-5), este rango ínfimo se lo atribuye a ellos por emplear su tiempo a actividades propias de las tribus. De esa forma, sus integrantes rechazarían todo indicio de modernidad, intelectualidad y progreso. Cabe destacar que el autor clasifica a las personas según sus razas para cerciorarse de su grado de inteligencia. Este pensamiento elitista también se halla en su tesis doctoral Filosofía y arte (1897b), en la que trata el problema de la cultura en la actualidad peruana, debido al modernismo, junto con la disolución del individualismo y la pérdida de la fe (la religión) (Mora, 2000: 34). Con respecto a este tema, Clemente Palma postula lo siguiente: «Los problemas filosófico y artístico son menos trascendentales, por cuanto ellos pertenecen a un orden 
más individual y, por lo mismo, son más reveladores y expresivos de la verdadera condición psicológica del hombre actual» (1897b: 5).

Más adelante, Gabriela Mora (2006) logra desplegar con epítome cómo se ha abordado el tópico de la sexualidad en los personajes femeninos de sus cuentos, como «Leyenda de Hachisch»y «Los ojos de Lina». Adicionalmente, Gonzalo Cea Monsalves (2009) estudia solo «Idealismos» y sintetiza su historia para luego analizar las nociones de amor y sexo. Para ello, se basa del argumento de Michael Foucault que consiste en que el acto sexual es peligroso y atenta contra la libertad. Esta propuesta se representa en el relato explícitamente. La evaluación de este crítico literario se respalda con equivocación de la postura de uno de los personajes, pues se conoce que el protagonista mantiene una idea desafortunada de la existencia y el amor, pero no es vinculada y sustentada bajo el concepto del terror. Ante este postulado, es insoslayable retomar el eje supeditado al pensamiento del autor: «Es la humanidad la que es loca, enferma o asesina; es una numerosa agrupación de hombres la que llega a esos extremos, violentada por un estado social deficiente» (Palma, 1897b: 5).

De igual modo, Basilio Ventura (2014) sostiene que su aporte primordial en la tesis es indagar su obra ensayística, en especial, Filosofía y arte. Se enfoca en «Las vampiras» para demostrar cómo los personajes portan valores o posiciones filosófico-éticas. Así, resulta simbólico desde su ideología. Para Clemente Palma (1897b: 11), el ateísmo ligado con el razonamiento es necesario para alcanzar el grado culminante de conocimiento. En ese sentido, la clase aristocrática es más merecedora de esa apropiación intelectual, que se conseguirá solo con la negación de lo que supone la subjetivación de la creencia en Dios. Para concluir, Díaz Choza (2015) asume y arguye de modo más exhaustivo y pormenorizado el proceso de secularización del escritor peruano, que la exégesis no ha investigado de forma tan concisa. Para esa confirmación, menciona a autores como Xavier Abril, Boyd Carter, Christian Elguera, Peter Elmore, Juan Carlos González Espitia, entre otros.

\subsection{Análisis literarios acerca de Cuentos malévolos}

De alguna manera, los críticos literarios han extrapolado un recurso de la Literatura para indagar esta obra literaria. Este se fundamentará a continuación.

Peter Elmore (1984) cuestiona Cuentos malévolos sobre la base de la narratología estructural, además de otorgarle una explicación política a su dis- 
curso. Para ello, contará con los términos de autor implícito y lector abstracto. El objetivo de su investigación es desligar lo literario de lo social; asimismo, sostiene que la obra de Clemente Palma es insular. Carlos Eduardo Zavaleta (1997) analiza las técnicas empleadas por el escritor en su libro: primero, observa una extensión media, puesto que sus cuentos no son ni tan breves ni tan extensos; y, segundo, no se detiene en la descripción del narrador en primera persona, en rigor, importarán más los detalles y el avance de la narración que lo subjetivo. Finalmente, en relación con las dos temáticas, el exégeta menciona que se tratan la lucha del bien contra el mal, la drogadicción, la moral y la religión, que se evidencian en las evaluaciones que hace de «Los canastos», «Una historia vulgar», «Los ojos de Lina», «La granja blanca»y «Leyenda de Hachisch». Su estudio se enfoca en la aplicación de las técnicas narrativas, que es necesaria comprender, pero no es la prioridad autoral. Más bien, lo que resulta factible indagar es el desarrollo y la indagación de este contenido, que ya había sido expuesto por Edgar Allan Poe. En ese sentido, es provechoso partir de los escritos efectuados por el autor (quien ha elaborado dos tesis acerca de las ciencias ocultas y el racismo: temas polémicos y equidistantes para la moralidad de la época). Gabriela Mora (2006) distingue los relatos de Palma según los tópicos. Verbigracia, especifica que «Las mariposas» y «Cuento de marionetas» son infantiles, no de terror. Más adelante, corrobora la diferencia

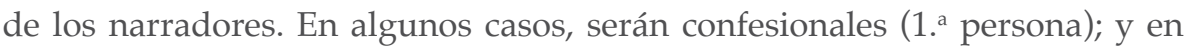
otros, utilizará el narrador omnisciente (3. ${ }^{a}$ persona), como en «El quinto evangelio», «Ensueños mitológicos», «El último fauno» y «Cuento de marionetas». Sánchez Franco (2007) realiza un estado de la cuestión de Clemente Palma. Honores (2013) señala que el escritor peruano recurre a elementos comunes de la narrativa nacional en esa etapa. Basilio Ventura (2014) se sirve del trabajo de Gabriela Mora. Díaz Choza (2015) indaga en torno a los postulados investigados por la hermenéutica del autor, con el propósito de conseguir una clasificación personal de tres periodos constituyentes (sincrónicamente). A la vez, se basa en su obra desde la hermenéutica social del texto y la teoría de los campos figurativos de la retórica general textual. Para terminar, Güich Rodríguez (2016: 53-58) analiza «La granja blanca» y «El quinto evangelio». En el primer relato, extrae la alusión al filósofo Kant por la cosmovisión errada con la que cuentan los personajes sobre la realidad. A su vez, esta se confronta con las colisiones entre el sueño y la vigilia. En el segundo caso, percibe la influencia de Goethe al ser articulado el romanticismo y lo fantástico, además de incorporarse el tópico del doble (un rasgo esencial de lo demoniaco). 


\subsection{Aproximación a lo terrorífico y el mal}

El terror y el mal son dos términos que buscan un efecto subjetivo de contrariedad en quien los padece. Durante años, se ha comprobado su inserción como antimodelos que distorsionan las creencias religiosas. Hacer uso de estos elementos solo será símbolo de que no se actúa con corrección, y mucho menos con valores positivos. Clemente Palma (1897) asumirá como terror todo aquello que se pueda construir desde el mundo interior para resolver dudas existenciales. De igual forma, este será un paradigma que subsane algún malentendido que no esté explícito en la Biblia. De ser así, esta noción revela que su funcionamiento no depende solo de lo psicológico o lo ético, sino que abarca lo religioso y lo antropológico. Al percibir esa pluridimensionalidad, es consecuente apreciar que el terror se manifiesta de distintas maneras, como la maldad. Nuevas modalidades de expresión ya han surgido y son de utilidad para validar el nexo que se ha originado también con lo demoniaco. Esto ocurre con la idea del doble, que se evidencia con la negación de la muerte, la multiplicidad de existencias y la práctica frecuente de acciones perversas, inherentes al ser humano. En ese sentido, es neurálgico tener una cosmovisión de que el terror y la maldad poseen un campo semántico amplio, del cual se derivan significantes afines. Frente a esa heterogeneidad, recurriré a los trabajos de los exégetas. El objetivo es averiguar cuáles han sido las variaciones de estos conceptos y cómo se han incluido en los cuentos de Palma.

Viñuales Guillén (1991) propone que el escritor peruano extrapola el tema del satanismo en sus relatos, con la influencia de Charles Baudelaire. Eso será notorio al mostrarse la expectativa de reinvertir la moral religiosa, en la que el Demonio es el motor del accionar de la sociedad. Otra es la labor de Carlos Eduardo Zavaleta (1997). Él se enfoca en el análisis de «En el carretón» para observar la exteriorización de rasgos terroríficos o mortales que anhelan la felicidad. Este tópico luego será vinculado con Cuentos malévolos. Para Clemente Palma (1897b: 15-16), la idea de satanismo es retomada a causa de la ignorancia de las personas. En el caso de la ciencia, se consideraría una patología, producto de una excitación cerebral. Esta noción se le ha atribuido injustamente a los materialistas y quienes incentivan el razonamiento, ya que de alguna forma contradirían a lo establecido como dogma de los discursos bíblicos.

Otras temáticas desarrolladas son detectadas por Gabriela Mora (2000). Una de ellas es el exterminio de los cuerpos como una prueba de amor, el mal insertado en la figura femenina, que lo aprecia en «Tengo una gata blanca», «Idealismos» $\mathrm{y}$ «Los ojos de Lina», al igual que lo gótico en «La granja blanca» 
o «Vampiras». Para ella, un suceso que aumenta el horror en «El príncipe alacrán» (Mora, 2000: 115-116) es cuando los alacranes aparecen frente al personaje. Ante esta formulación, es notable un anacronismo de esa situación. El horror ya no se percibe como antes. Mora (2000) alude a «Parábola», «El quinto Evangelio» $\mathrm{y}$ «El hijo pródigo». En estos se presenta la figura del mal personificada por el mismo Diablo. Esto es un encauzamiento de Edgar Allan Poe, incluso de Baudelaire. A ello, se le añade el esoterismo: la magia, el diabolismo y el espiritismo. En Cuentos malévolos, el autor se opone a la estética tradicional, en la que lo bello se asocia con lo bueno y lo sagrado (Dios). Según Mora (2000: 63), la dicotomía bien-mal se ausculta no solo en las religiones, sino también en las culturas. El cuentista peruano revela una predilección por la temática del doble y el conflicto de la identidad desorbitada que se encuentra amenazada (Mora, 2000: 115). Todo eso va construyendo una idea acerca del mal, que se complementa con la cosmovisión personal de Clemente Palma (1897b). Él considera que esta es justificable si una doctrina no está bien condensada. Es a partir de ese instante que hallará una oportunidad para rechazar los discursos de naturaleza divina. Estos serán repudiados por carecer de enunciados lógicos. En ese sentido, propiciar una intención perversa y cuestionadora de la religión será una advertencia a cómo se han estado erigiendo los discursos históricos. Desde ese momento, será de mucho interés preservar la coherencia de las palabras y aceptar que no existe ninguna normativa que sea estática e inamovible. Ese mismo criterio será replicado en la percepción de la humanidad que tiene el autor. Obviar ese criterio solo significaría la evolución de esa ignorancia ideológica, que él no está dispuesto a acatar. Esa postura es válida merced a que origina una concientización en torno a lo que impera en la sociedad; encima, brinda más argumentos con los que emergerán debates y teorías. Hasta ese entonces, no solo la religión ha atravesado por esa indagación, puesto que otros temas sociales han incurrido en la misma dinámica, como la democracia, la inserción progresiva de la mujer en distintos ámbitos de la vida o el acceso inmediato al conocimiento por las tecnologías.

Prosiguiendo con los estudios de la exégesis, Sánchez Franco (2007) se enfocó en Historietas malignas y la concepción de drogadicción. Honores (2013) ubica a Clemente Palma en el primer horizonte de la literatura peruana de terror (fines del siglo XIX hasta 1940), ya que alude al género fantástico o el relato terrorífico. Sostiene que oscilan los tópicos del mal, sexo y la mujer de forma negativa, con orígenes bíblicos. Indica que el escritor peruano se vale de Mors ex vita y «La granja blanca» de Cuentos malévolos, para cerciorarse de elementos religiosos en lo fantástico y lo perverso. Para Palma (1897b: 28), 
existiría una correspondencia de moralidades e ideas entre hombre y mujer, la cual no estaría limitada o desfavorecida.

Díaz Choza (2015) considera que su obra revela su afinidad por la religión, de la que no es partícipe (ateísmo). Analiza «Parábolas», «El día trágico», «El quinto evangelio», «El hijo pródigo», «El último fauno» $\mathrm{y}$ «Ensueños mitológicos», en los que se incorpora la lógica secular, a causa de que se cuestiona la existencia de Dios y el cristianismo. Configura el prototipo del Diablo y Cristo, retomando los conceptos de Nietzsche, la Biblia y la crítica literaria. Díaz Choza se regirá del tema de la secularización, notorios en la muerte de Dios (tal como lo asume Nietzsche), la sacralización del mundo, la representación literaria del Diablo, etc. Estos talantes erigirán la obra completa del cuentista peruano. Para Clemente Palma (1897b: 5), el ateísmo es propicio por la idea de que la ciencia manifiesta paulatinamente la sinrazón que era justificada mediante la intervención de Dios. Afirmar ese precepto es equivalente a asegurar la buena constitución de los grupos sociales, porque estos no se sustentan de creencias, sino de estatutos y leyes indispensables para gobernar.

\section{Influencia del terror romántico de Edgar Allan Poe}

El siglo XIX se caracteriza por el planteamiento de ideologías opuestas a la religión y la moral desde una cosmovisión demasiado rígida. Con Edgar Allan Poe, se empieza a proponer un tópico auténtico en el desarrollo de la literatura. Las narraciones rudimentarias del romanticismo norteamericano poseen un tratamiento peculiar en función de lo terrorífico y una prosa muy poética. Su estilo alude a tropos y mucha sonoridad en su discurso. Son notorias la ansiedad y la angustia que atravesaban sus personajes por lo terrorífico que resultaba escapar de un orate o percatarse de que algunos de ellos fueron enterrados vivos. Estos ejemplos están en su libro compilatorio Narraciones extraordinarias, en el que se encuentran «El gato negro», «El pozo y el péndulo», «La caída de la casa Usher», «El corazón delator», «Los crímenes de la calle Morgue» $\mathrm{O}$ «La carta robada».

El terror que fragua Clemente Palma busca justificar filosóficamente nociones inusitadas, que poseen un trasfondo perverso. Para que esa formulación sea aceptada por el lector, el cuentista requerirá de elementos del romanticismo, debido a que su prosa ostentosa pretenderá convencer a través de los raciocinios que expone cada personaje, como el de adorar la figura inerte de una mujer, obviar el matrimonio por tratarse de un convenio egoísta y 
frustrante, preferir la maldad y mantener el regocijo provocado por estados que perturban el común de los hábitos humanos, como el de comer y dormir.

Estos relatos adoptan una temática terrorífica, en la que lo irracional ejerce un primer plano para desembocar en situaciones y atmósferas de angustia o temor. Verbigracia, en «La caída de la casa Usher» se percibe un desmoronamiento de la estructura de ese asentamiento sin explicación alguna, además de detectar anomalía con respecto a la ambientación que se recrea mediante uno de los personajes. En «Los crímenes de la calle Morgue» y «La carta robada» se introduce un talante concomitante de lo terrorífico: la necesidad de develar un secreto que resolverá el misterio asociado con el generador de crímenes o acontecimientos horripilantes, como la muerte. La necesidad de querer racionalizar los actos y proporcionarles un orden lógico para entender exactamente cómo acaecieron los hechos que finiquitaron en una situación terrorífica es propia de la configuración de las novelas de misterio o espionaje. Edgar Allan Poe incorpora en sus narraciones al detective Auguste Dupin, quien será esencial para que el personaje se identifique con el lector, debido a que, conforme su participación vaya representándose, irá desentrañando información concienzuda de cómo se realizaron los sucesos por investigar. Este personaje de ficción es un notorio encauzamiento en los relatos de Clemente Palma, como en «La granja blanca» o «Las vampiras», en los que se alude al interesado en dilucidar un misterio: sustentar el porqué del comportamiento extraño de Cordelia en «La granja blanca», quien se autorretrataba a solas y evitaba que la vieran:

Llegaba a su término el segundo año de nuestra permanencia en la Granja Blanca. Cordelia estaba concluyendo su retrato. Una mañana tuve la imprudencia de atisbar por el ojo de la cerradura de mi gabinete, y lo que vi me hizo estremecer de angustia: Cordelia lloraba amargamente; tenía las manos sobre el rostro, y su pecho se levantaba a impulsos de los sollozos ahogados... A veces oía un ligero murmullo de súplica: ¿quién? No lo sé (Palma, 2006: 263).

Así, se descubrirá el misterio del personaje Stalisnas, quien ha empezado a perder mucho peso y no se despliega la razón por la que su pareja tiene conductas raras, junto con la gente circundante en «Las vampiras»:

Hubo un tiempo en el que enflaquecí extremadamente. Mis brazos y mis piernas se adelgazaron de una manera desconsoladora, y mi busto, antes musculoso y fuerte, degeneró de tal modo que se diseñaba claramente, bajo la piel lívida y pegajosa, la maquinaria ósea de mi tórax (Palma, 2006: 328). 
A propósito de esta influencia directa, se confirman las preferencias perentorias del autor acerca de su función de director de la revista Variedades (1908-1931), debido a que en esta se exponen publicaciones de poemas, ensayos, notas periodísticas, caricaturas, imágenes y cuentos de autores extranjeros, como los siguientes: «La alucinación de Mr. Forbes» (Variedades, Lima, núms. 1-20), de Julio Perrin; «Los guías italianos» (Variedades, Lima, núm. 2) y «El diario de Eva» (Variedades, Lima, núms. 44-47), de Mark Twain; «La máquina de pensar» (Variedades, Lima, núm. 33), de Miguel de Unamuno; «Las rosas» (Variedades, Lima, núms. 55-56), de Guy de Téramond; «El nuevo acelerador» (Variedades, Lima, núms. 33-34), «La esfera de cristal» (Variedades, Lima, núms. 39-43) y «El hombre pájaro» (Variedades, Lima, núms. 48-49), de H. G. Wells; junto con «Filosofícula» (Variedades, Lima, núms. 39 y 45) y «El espíritu de la galantería» (Variedades, Lima, núm. 53), de Leopoldo Lugones, entre otros autores como Arthur Conan Doyle, Gastón Leroux y Juan José de Soiza Reilly.

De la narrativa romántica de terror de Edgar Allan Poe, se recupera el interés por querer recrear situaciones en las que el lector es testigo de que existe un desconocimiento en los romances por uno de los integrantes, pues otro personaje será el que simbolice el mal o lo irracional, mientras que la otra parte tan solo se trate de la víctima de las constantes represiones que le propina. Esta forma de dominar el terror, ese psicodinamismo, se expone en los relatos de Clemente Palma, aunque no en todos. A continuación, detallaré la funcionalidad de esta categoría, aplicada en las relaciones terroríficas de los personajes de Cuentos malévolos. Por ejemplo, en «Los canastos», el protagonista es caracterizado como una entidad que durante la temporada de invierno adopta conductas malignas. Una de ellas es que lastima a su mujer, quien se asusta de su comportamiento. Por el contrario, sigue coligado con él:

Os juro que yo soy bueno, que soy un buen padre de familia, pero sólo en la época en que hay sol en este cielo brumoso. ¡Oh!, la bruma invernal me hace daño y me convierte en malvado. Si yo fuera poppe, en verano rendiría culto a Dios, pero en invierno le volvería la espalda y me entregaría a darle gusto al diablo. En el invierno le amo, siento que se introduce en mi ser, que estruja mi espíritu y aviva el fuego de mis malos instintos; entonces me siento nihilista, capaz de ser ladrón y asesino; lo rojo me excita, y lo afilado y lo agudo me fascinan. Cuando llega la época de las primeras nevadas, mi mujer me dice: «Marcof, padrecito mío, ya las malas ideas comienzan a fulgurar en tus ojos. Ya viene el tiempo en que no vives sino gruñendo y blasfemando, en que nos aporrea a tus hijos y a mí. Mira, no te alejes de la estufa, porque el hielo te hace malvado...». (Palma, 2006: 179) 
En «Idealismos» $\mathrm{y}$ «Una historia vulgar», se encuentra una visión distorsionada del amor por el personaje masculino, ya que él plantea la idea de que uno debe morir para que el amor que sienten trascienda, sin contenciones y con libertad absoluta: el matrimonio sería esclavizante. El narrador deja manifiesto sus paradójicos sentimientos hacia su amada: «Si leyerais estas páginas no podríais comprender jamás que la muerte de mi adorada prometida, de mi inocente Luty, pudiera alegrarme profundamente. Al contrario, sentiríais hacia mi viva repulsión y gran horror por mi crueldad» (Palma, 2006: 184). En «El último fauno», un personaje mitológico, y a la vez terrorífico, secuestra a una novicia. Entre ellos, surgirá el amor. Ese tipo de romance forzado resulta terrorífico, debido a que ambos no son de la misma especie y la interrelación no ha sido voluntaria. Lo curioso es que al final la hermana Ágata de la Cruz se resigna a aceptar ese compromiso, por la sorpresa que genera el fauno con su fortaleza y su violencia; incluso, se proyecta al futuro con él y sus costumbres: «Júrame, fauno, que creerás en la divinidad de nuestro Señor Jesucristo» (Palma, 2006: 197). Ese mismo romance se propone en «Cuento de marionetas», en el que el rey Pierrot IV, a pesar de estar casado, se enamora de la Luna, y empieza a tener un vínculo enfermizo, sin importar que este sea solo contemplativo. Ante este estrambótico suceso, se concluye como moraleja lo siguiente: «En amor no debe llegarse a la posesión, a la apreciación exacta del objeto amado. Poseer o conocer es matar la ilusión; es odiar, es encontrar ridículo el objeto amado, es hacerle perder todo el prestigio y encanto» (Palma, 2006: 233). El fin es convencer al lector de que ese tipo de relación es asequible y mejor que el natural entre las personas. También, es notorio en «El príncipe alacrán», en el que la reina de los alacranes le ofrece a Feliciano que se case con ella para intercambiar dotes mediante la procreación: «Yo quiero lograr por el amor lo que mi esposo anhelaba y que tu amor puede darme. (...) Tu vida me pertenece y quiero utilizarla para engendrar un hijo que tenga mi raza y tu inteligencia» (Palma, 2006: 310). En «La granja blanca» y «Las vampiras», los personajes varones actúan como espías que desvelan el secreto de sus parejas. En ambos casos, permanecen angustiados y temerosos por las conductas de ellas, quienes ocultan su verdadera identidad frente a ellos para no perderlos. Ante la revelación de que Stanislas interactúa con una vampira, el doctor Max Bing le aconseja algo ilógico: «Créeme, Stanislas, es muy vasto el poder de la personalidad humana. (...) Cásate hoy mismo; si no es hoy, mañana; y si no es mañana, lo más pronto que te sea posible. Ese es tu remedio. Y... el de tu novia» (Palma, 2006:). Esa sugerencia le reduce importancia a las pesadumbres por las que atraviesa el personaje. 
En una conferencia, Santiago Roncagliolo (2016) sostuvo que el romanticismo consiste en una reacción ante lo racional y es asociado más con el terror. Si esa adhesión es perentoria, su definición desde lo semántico es más explícita, puesto que es más evidente la oposición bueno-malo. Esa formulación dicotómica sería posible a partir de las interrelaciones amorosas, a causa de que en sus acciones exentas de conexiones predomina solo una de las direcciones: la positiva o la negativa. Para designar el concepto de terror romántico, se tendrá en cuenta que las propuestas de Edgar Allan Poe, en torno al romanticismo norteamericano, son una modalidad de percatarse del desenvolvimiento de conductas anómalas subyacentes a la temática del terror; es decir, en medio de ese romance, se desarrolla el psicodinamismo del terror romántico. Indefectiblemente, al mostrarse un indicio de terror es porque se piensa en la muerte. Esa angustia por no querer desligarse de la vida es la que acarrea acápites asociados con el afianzamiento en la religión, la moral y el amor. Esto es asequible analizarlo desde lo cultural. En una sociedad tan organizada (como la de Edgar Allan Poe o Clemente Palma), se corrobora el establecimiento de las leyes, un orden político y diversas formas de estandarizar a la sociedad. No será congruente pensar en la muerte ocasional, pues esta producirá temor, una sensación de no considerar la vida y la muerte como procesos que concluyen negativamente (Martí García, 2014: 6). Esto resulta desagradable, inaceptable e inapropiado. Por el contrario, la vida se hallará en todas partes para Palma (1897b: 21), tendrá un espacio que trascenderá más allá de cualquier concepto filosófico o religión alguna. Así, la muerte no mostraría una acepción terrorífica: se trataría de una proyección y una variación alterna en la que la existencia adopta un rol esencial. Menos aún, sería erróneo afirmar que prevalece un interés del autor por propiciar la omnipotencia de una posesión demoniaca. No es palmario ningún tipo de alianza implícita ni favoritismos. Abordar entidades con cualidades perversas o padecimientos insanos no significa que sean una predilección; más bien, las situaciones que se forjan desde esa modalidad permiten reflexionar sobre la grandilocuencia que se obtiene al creer en Dios. Esto se aprecia con frecuencia al introducirse personajes que son devotos de la religión católica. Ellos consideran que la adoración al Señor es una oportunidad para lograr la erradicación de la maldad del mundo. Por ese motivo, se cercioraría una relación totalmente diferente, una que revela un escenario donde se confrontan elementos opuestos.

Asumiendo la acepción de la Real Academia Española (2020), la noción de muerte se comprende como el cese de la vida, y con ello el abandono total de las demás emociones. La religión católica será de importancia, ya que insta 
a las personas a que asimilen la muerte como etapa de la vida. Este rol es muy complejo por la percepción repulsiva de los seres humanos a fenecer hasta el último instante de su existencia. Referencias bíblicas rinden testimonio de lo aludido, como cuando los discípulos de Jesucristo se avergüenzan de su compañía antes de ser crucificado. Temen ser apedreados o crucificados como le pasará a Él. En ese sentido, la instrucción ético-religiosa no asegura que uno se resigne a la muerte en el momento en que esta se aproxima. Es por eso que Clemente Palma (1897b: 6-7) asevera que las doctrinas morales y religiosas se adaptan con el transcurrir del tiempo a las necesidades humanas. La razón se impondrá como discernimiento para clasificar los acontecimientos históricos y culturales.

\section{Análisis de Cuentos malévolos (1904) enfocado en el terror}

Extrapolaré la noción del terror según las constantes que se cercioran en la obra, con el objetivo de pormenorizarlo como concepto. Particularmente, para Clemente Palma, esta sirve de utilidad a fin de fundamentar que la mayoría de sus personajes opta por la convivencia con la maldad. Esta resulta adyacente a su naturaleza a través de sus pensamientos, pero también es adquirible. Sin embargo, siempre será este talante el que perdure con sus respectivas configuraciones.

Con la finalidad de hallar elementos terroríficos en los relatos, he adherido ideas consuetudinarias, que permiten el tratamiento de las narraciones con autonomía. A la vez, asumo que el terror se rige con anacronismo, aunque fue consistente en su determinada época de publicación. Los tópicos que se argumentarán son los siguientes: el triunfo del mal sobre el bien, la descripción de escenas terroríficas, el desequilibrio psicológico en los personajes, su presencia irreal y maligna, el rechazo del catolicismo y la búsqueda de suspenso.

Primero, la victoria del mal por encima del bien es característico en Cuentos malévolos. Su temática es progresiva. Si un personaje desea adoptar la maldad como prioridad, no tendrá oportunidad de reivindicarse; es más, fenecerá con ese criterio. Eso suscita en «Los canastos». En este, el protagonista Marcof goza de la maldad cuando está en temporada de invierno: suele golpear a su esposa y sus hijos, además de ser indiferente ante el sufrimiento humano, ya que no reacciona frente a lo desagradable que atraviesa el anciano sordo Vassielich: «Pude avisarte (...). Mas ¿para qué? Mañana habrías olvidado el favor que te hacía: en cambio, cuando te lleven a la cárcel, y tu mujer y 
tus hijos lloren en la miseria, te acordarás de mí, cierto que para maldecirme» (Palma, 2006: 182).

Segundo, la reconstrucción exhaustiva de escenas terroríficas es un requisito para causar efectos repulsivos en el lector, como pasa en «Los ojos de Lina», cuando el narrador-personaje detalla los ojos de su amada de manera tenebrosa y hasta demoniaca. Algo similar ocurre con «Las vampiras», en el que se aprecia un acto de canibalismo, con mujeres que extraen la sangre de un joven; o como acaece en «El hijo pródigo», en el que se ostenta la figura de Satanás, por medio de la descripción de la pintura de Néstor: «Vibran de emoción ante las coloraciones exóticas, los simbolismos extrañamente sugestivos, las figuras pérfidas, las carnes mórbida y voluptuosamente malignas, los claroscuros enigmáticos, las luces grises o biliosas y las sombras fosforescentes (...). Todo esto había en El hijo pródigo» (Palma, 2006: 248).

Tercero, el desequilibrio psicológico se evidencia en los personajes, que es asociado con la locura o el deseo de asesinar, como acontece en «Idealismos» al mostrar una conciencia supeditada a la idea de que la muerte en su pareja es una liberación y una proyección abundante del amor. En «Leyenda de Hachisch», el protagonista busca que la mujer a la que amará sea maligna y diabólica; caso contrario, la repudiará. Asimismo, se pretende destacar aspectos degradables, como suscita al rememorar e imponer su imagen inerte: «Viajé mucho para debilitar el recuerdo de la difunta Leticia, de la delicada Leticia. Nuestras locuras y caprichos debían matarla y así fue. Su cuerpo anémico había nacido para el amor burgués» (Palma, 2006: 276).

Cuarto, los personajes irreales tienen un rol maligno, como se observa específicamente en «El último fauno». En este, un ser mitológico secuestra a una de las monjas adolescentes para que sea su esposa. En «El quinto evangelio», el Diablo se patentiza para retar a Jesús crucificado, burlarse y hacerle comprender que todo su plan salvador ha sido en vano. «La granja blanca» se caracteriza por exhibir a un personaje que tiene dimensiones heterogéneas: ha fallecido, pero alguien puede verla y sentirla con naturalidad. También, ha reencarnado y se apropia de dos roles con simultaneidad. El protagonista intenta ofrecer una explicación razonable en torno a lo que está aconteciendo: «La vida de usted, maestro, la mía, la de todos, son ilusiones aéreas, sombras que sin lógica ni firmeza cruzan la región del ideal» (Palma, 2006: 272).

Quinto, el catolicismo es rechazado. Esto conlleva que se cuestione o se niegue el mensaje bíblico. Verbigracia, en «Parábola», «El quinto evangelio»y «El nigromante» se alude directamente al Diablo como protagonista y héroe de las tramas planteadas, tal como pasa con el anciano que reside en el castillo 
de Suabia, quien requiere sabiduría directa de Satanás: «Solo el diablo podía darle la fórmula completa y resolvió acudir a sus consejos, como había ocurrido otras veces en sus investigaciones sobre la piedra filosofal o el homunculus» (Palma, 2006: 322).

Sexto, el suspenso se articula en estos cuentos, debido a que se busca propagar la sensación de terror en los personajes, como en «Las vampiras», en el que la víctima de esta criatura desconoce el motivo de su enflaquecimiento. Igual sucede en «Una historia vulgar», en el que se desarrolla el suspenso en los diálogos, pues estos ralentizan la solución a sus padecimientos. Esto acarrea que el personaje reflexivo se someta a indagaciones apresuradas. Para

que surja el efecto anhelado, se construye una circunstancia pormenorizada que confronta con lo inquietante, tal como se muestra a continuación: «Estaba yo una tarde escribiendo a mi familia, (...), cuando entró Ernesto pálido y convulso. Me echó los brazos al cuello y se puso a llorar. Nunca he oído sollozos más angustiosos y que expresaran un dolor más agudo» (Palma, 2006: 210).

\section{Conclusiones}

El terror que fragua Clemente Palma se exhibe como una reacción a su época, la cual terminaba de experimentar la afinidad con la creencia religiosa a tal punto de negar y sentenciar cualquier lógica que intentara cuestionar o erradicar las doctrinas preexistentes. Este concepto es asociado con lo demoniaco, que es utilizado en el discurso del escritor peruano con el propósito de enriquecer las variantes de abordar una secuencia narrativa, como ocurre al incorporar la duplicidad de participantes, la anomalía en situaciones e ideas, la descripción de acontecimientos propios de gente insana, etc. Todo ello lo logrará con su prosa perlocutiva y afiliada al romanticismo. Por ello, el tratamiento de las relaciones de pareja en su obra será fundamental para evidenciar las vertientes heterogéneas por las que lo terrorífico se muestra en la realidad. En ese sentido, este elemento fantástico estará patente en la producción del autor, con sus respectivas estructuras y contenidos, que incentivan la desarticulación consuetudinaria del hombre en función de su moralidad y su creencia en Dios.

El terror en la literatura pervive. Sus manifestaciones han variado en torno al tiempo. Aún se percibe no solo en los relatos de esta índole, sino en representaciones ideológicas o culturales. Entonces, no consiste en lo que señalaba Rafael Llopis Paret (1969) al mencionar que el terror, con el decurso de la historia, estaba atravesando por un descenso progresivo que concluiría con su desa- 
parición. Ante la confirmación de la existencia del terror en la literatura, el terror romántico se exterioriza como una de las múltiples exposiciones de terror perentorias y vigentes en la actualidad, mas este se distingue por originar la destrucción del concepto del amor, que es explayado, en primera instancia, con la aniquilación del personaje que cree realmente en la unión espiritual y carnal de la pareja en un tiempo diacrónico y trascendente. Palma propone que la inclusión de un andrógino en la sociedad sería más propicia que la conexión física y emocional de un hombre con una mujer. Por ello, formula lo siguiente: «Son mitades que se buscan: no encontrarse es un dolor: lo justo, lo lógico es suponer que el estado feliz, que el estado perfecto es aquel en que las dos medias entidades no necesitan buscarse, porque nacen juntas» (1897b: 26).

Como consecuencia, el personaje manipulador también resultará perjudicado, porque al contar con el soporte emocional necesario, prácticamente desaparecerá. No obstante, como bien se señaló, no importa considerar la última repercusión del terror romántico, sino cómo este se adecúa a un psicodinamismo de confrontación entre el bien y el mal, corroborado en el romance exteriorizado: el intento de manipulación, la orientación a situaciones arriesgadas y peligrosas por el manipulador, la ausencia de personajes que procuren reconducir esa atmósfera tensa y de suspenso a ambientes más sociables y tradicionales, etc. Todo ello parte de la idea de que la mujer adopta un nuevo rol a inicios del siglo xx, al rechazar la habitual forma de establecer un vínculo amoroso y sexual con el hombre. Esa transmutación afectaría con notoriedad a su pareja, tal como lo expone Clemente Palma en el siguiente fragmento: «Al mismo tiempo que la mujer crece, el hombre se empequeñece, se afemina» (1897b: 4).

En fin, la terminología propuesta como terror romántico comprende la manera de representar la relación de pareja caracterizada por una dicotomía entre la concepción inmanente del amor frente a la distorsión del mismo, junto con conductas anómalas y de riesgo para la vida del personaje.

BiBliografía

Basilio Ventura, Wilmer (2014): El pensamiento estético de Clemente Palma en dos ensayos: Excursión literaria y Filosofía y arte, Universidad Nacional Mayor de San Marcos, Lima. Tesis de licenciatura.

Cea Monsalves, Gonzalo (2009): «Tentación, agonía y muerte en "Idealismos" de Clemente Palma», Atenea, núm. 499 (I semestre), pp. 149-156. 
DíAz Choza, Mateo (2015): La secularización en los ensayos y la narrativa de Clemente Palma, Universidad Nacional Mayor de San Marcos, Lima. Tesis de licenciatura.

Elmore, Peter (1984): Clemente Palma: Cuentos malévolos y la cuestión cosmopolita, Pontificia Universidad Católica del Perú, Lima. Tesis de bachiller.

Gnutzmann, Rita (1981): Novela y cuento del siglo xx en el Perú, pról. José Morales Saravia, núm. 21, Universitat d'Alacant, Alicante.

Güich Rodríguez, José (2010): «Apuntes sobre narrador no confiable en "Los ojos de Lina"», Tinta Expresa, núm. 4, pp. 87-92.

— (2016): «Claves secretas del romanticismo en la narrativa de Clemente Palma», en José Güich, Carlos López y Alejandro Susti, Del otro lado del espejo. La narrativa fantástica peruana, Fondo Editorial de la Universidad de Lima, Lima, pp. 47-63.

HonOREs, Elton (2013): La civilización del horror, El Lamparero Alucinado, Lima.

KASON, Nancy (1988): Breaking traditions. The fiction of Clemente Palma, Bucknell University Press, Lewisburg.

Llopis PARET, Rafael (comp.) (1969): Los mitos de Cthulhu: H. P. Lovecraft y otros. Narraciones de horror cósmico, trad. Francisco Torres Oliver, Alianza Editorial, Madrid.

López GonZÁLVEZ, Encarnación (2014): «De la tradición gótica en la literatura hispanoamericana: "La Granja Blanca", de Clemente Palma», Brumal. Revista de Investigación sobre lo Fantástico, vol. II, núm. 2, pp. 177-186.

Martí García, Celia (2014): Miedo a morir: estudio experimental de las repercusiones de la angustia ante la muerte en población joven; aplicaciones en procesos de fin de vida, Universidad de Granada, Granada. Tesis doctoral.

MorA, Gabriela (2000): Clemente Palma. El modernismo en su versión decadente y gótica, Instituto de Estudios Peruanos, Lima.

- (2006): «Los Cuentos malévolos de Clemente Palma: integración más allá del bien y del mal», en Pablo Brescia y Evelia Romano (coords.), El ojo en el caleidoscopio, Universidad Autónoma de México, México.

OLIJNYK, María Julia (2013): «Visiones de amor y muerte en dos cuentos malévolos de Clemente Palma», en Adriana Astutti, Irina Garbatzky y Javier Gasparri (eds.), III Congreso Internacional "Cuestiones Críticas", Centro de Estudios de Literatura Argentina y Centro de Teoría y Crítica Literaria de la Facultad de Humanidades y Artes de Universidad Nacional de Rosario; disponible en <https: / / bit.ly / 2sBkFlP> [22-01-2020].

PALma, Clemente (1897a): El porvenir de las razas, Universidad Nacional Mayor de San Marcos, Lima. Tesis de bachiller.

- (1897b): Filosofía y arte, Universidad Nacional Mayor de San Marcos, Lima. Tesis doctoral.

- (1904): Cuentos malévolos, Impresión Salvat, Barcelona.

- (1912): Cuentos malévolos, Lib. Paul Ollendorff, París.

- (1959): Cuentos malévolos, Nuevos Rumbos, Lima.

- (1974): Cuentos malévolos, Ediciones Peisa, Lima.

- (2006): Obras esenciales, ed. Ricardo Sumalavia, Pontificia Universidad Católica del Perú, Lima.

Real Academia Española (2020): Diccionario de la Real Academia Española, disponible en $<$ http: / / dle.rae.es / ?w=terror $>$ [21-01-2020]. 
RonCAgliolo, Santiago (2016): «El terror en la literatura», Universitat de Barcelona, Barcelona, disponible en <https: / / youtu.be/UwyPJLJxM-U> [22-01-2020].

SÁNCHEZ Franco, Moisés Samuel Ysmael (2007): La representación del sujeto aristócrata y del sujeto juvenil drogado en Historietas malignas de Clemente Palma, Universidad Nacional Mayor de San Marcos, Lima. Tesis de licenciatura.

Sumalavia, Ricardo (2006): "Clemente Palma y el modernismo peruano: la búsqueda del ideal», en Clemente Palma, Obras esenciales, ed. Ricardo Sumalavia, Tomo I, Pontificia Universidad Católica del Perú, Lima, pp. 9-39.

- (2014): La prose moderniste péruvienne et la vision de la modernité chez Manuel González Prada, Clemente Palma et Ventura García Calderón, Université Michel de Montaigne Bordeaux III, Pessac. Tesis doctoral.

Viñuales Guillén, Pedro Pablo (1991): «Clemente Palma, la malicia del contador», Anales de Literatura Hispanoamericana, núm. 20, pp. 103-118.

Zavaleta, Carlos Eduardo (1997): El gozo de las letras, Fondo Editorial de la Pontificia Universidad Católica del Perú, Lima. 